\author{
${ }^{1}$ Institute of Genetics and Animal Breeding Polish Academy of Sciences, Jastrzebiec, Poland \\ ${ }^{2}$ South Valley University, Qena, Egypt \\ GRAZYNA SENDER ${ }^{1}$, KARIMA GALAL ABDEL HAMEID², AGNIESZKA KORWIN- \\ KOSSAKOWSKA $^{1}$, MAGDALENA SOBCZYNSKA ${ }^{1}$
}

\title{
Association of the BoLA-DRB3 alleles with estimated breeding value for somatic cell count in Polish dairy cattle
}

\begin{abstract}
Introducing resistance to mastitis into breeding programmes for dairy cattle seems to be one of the possible methods for limiting the increasing number of mastitis cases. Looking for candidate genes for genetic markers is one of the strategies. The BoLA-DRB3 alleles have considerable promise as potential mastitis marker.

The objective of the study was to evaluate relationships between two BoLA-DRB3 alleles (BoLA-DRB3.2*16 and BoLA-DRB3.2*23) and estimated breeding value (EBV) for somatic cell count (SCC) in Polish dairy cattle. A total of 525 Polish Holstein cows in two experimental farms were evaluated for test-day SCC. The polymorphism of BoLA-DRB3 gene was identified using the MPT-PCR method. The variance components for test-day SCC were estimated by the REML method using animal model. The breeding value of SCC was calculated according to the BLUP method. Linear contrast between model-adjusted breeding values of SCC for all animals was used to test for differences between genotypes. In Polish Holstein cows population BoLA allele $D R B 3.2 * 23$ was associated with increase of EBV for SCC in milk. It was observed increase of EBV for SCC from cows carrying this allele comparing to cows carrying BoLA-DRB3.2*16 $(\mathrm{p} \leq 0.07)$ or other alleles $(\mathrm{p} \leq 0.01)$.
\end{abstract}

Key Words: BoLA-DRB3, somatic cell count, mastitis, breeding value, dairy cattle

\section{Zusammenfassung}

Titel der Arbeit: Beziehungen zwischen BoLA-DRB3 Allelen und dem Zuchtwert für die somatische Zellzahl bei polnischen Milchkühen.

Die Einbeziehung der Mastitisresistenz in Zuchtprogramme für Milchrinder ist eine Möglichkeit, um den Anstieg von Mastitiserkrankungen zu begrenzen, wozu die Suche nach genetischen Markern hilfreich sein kann. BoLA-DRB3 Allele besitzen dabei ein beträchtliches Potential. Ziel vorliegender Arbeit war die Untersuchung der Beziehungen zwischen zwei BoLA-DRB3 Allelen (BoLA-DRB3.2*16 und BoLA-DRB3.2*23) und dem Zuchtwert für die somatische Zellzahl (SCC). Bei 525 Polnischen Holstein Kühen aus zwei Betrieben erfolgte die SCC Bestimmung aus Testtagsmilchproben. Der BoLA-DRB3 Polymorphismus wurde mittels der MPT-PCR Methode ermittelt. Die Varianzkomponentenschätzung erfolgte mit REML und dem Tiermodell sowie die Zuchtwertschätzung für SCC mit BLUP. Der Lineare Vergleich zwischen den angepassten SCC Zuchtwerten aller Tiere konnte für den Test zwischen den Genotypen genutzt werden. Im untersuchten Tiermaterial war das BoLA-DRB3.2*23 Allel mit einem steigenden Zuchtwert für SCC korreliert. Dieser höhere Zuchtwert für SCC bei Kühen mit diesem Allel unterschied sich gegenüber den BoLA-DRB3.2*16 Tieren mit $\mathrm{P} \leq 0,07$ und gegenüber dem von Tieren mit anderen Allelen signifikant mit $\mathrm{P} \leq 0,01$.

Schlüsselwörter: BoLA-DRB3, somatische Zellzahl, Mastitis, Zuchtwert, Milchkühe

\section{Introduction}

Mastitis is an example of a disease for which breeding could improve resistance. The suitable parameter for selection to reduce incidence of mastitis proved to be somatic cell count (SCC), where genetic correlation between SCC and incidence of clinical mastitis (CM) has been demonstrated (SHOOK 1989, SHOOK and SCHUTZ 1994, 
ROGERS et al. 1996). SCC was included in the breeding goal for dairy cattle in several countries (SCHUTZ 1994, REENTS et al. 1995, BOICHARD and RUPP 1997).

Looking for candidate genes is another strategy introducing resistance to mastitis into breeding programmes (KÜHN et al. 2008). The major histocompatibility complex (MHC) is known to play a critical role in immune response and the MHC genes are the promising candidate genes for many disease traits. Identification of genes that are associated with reduced mastitis has been focussed up to date on the MHC genes (Tab. $1)$.

The bovine MHC was originally defined by antisera raised in recipients of skin transplants and in multiparous cows (SPOONER et al. 1978). The antigens recognized by these antisera were collectively called the bovine lymphocyte antigen (BoLA) system (SPOONER et al. 1979).

The BoLA complex is located on the short arm of chromosome 23 and is organized into three classes (I, II and III). In the BoLA class II region, only the expression of the BoLA-DRB3 gene, which is highly polymorphic were detected (SIGURDARDOTTIR et al. 1988), and 103 alleles have been identified (TAKESHIMA et al. 2002). As a result of this polymorphism as well as its functional importance the DRB3 locus and its gene products are among the best defined in cattle. The exon 2 of BoLA-DRB3 encodes peptide-binding residues and is the most variable region of the class II alleles. The polymorphism of exon 2 is generated by (i) the occurrence of parallel point mutations due to selective pressure (KLEIN and O'HUIGIN 1995, O’HUIGIN 1995), and (or) (ii) intraexonic sequences exchange (intragenic recombination / interallelic recombination). Both mechanisms result in allelic diversity at this locus (MIKKO and ANDRESSON 1995, MIKKO et al. 1997).

Several studies investigated the relationships between BoLA class II alleles and different mastitis indicators (Tab. 1). All of them focused on the exon 2 of the class II DRB3 locus. There are many alleles of BoLA-DRB3.2 associated with SCC and susceptibility and (or) resistance to CM. Most of these studies focused only on phenotypic measure of mastitis (SCC and CM) only KELM et al. (1997) evaluate breeding value of SCC (Tab. 1).

The objectives of this study were to find out associations between test-day SCC and breeding value of SCC as a measure of mastitis and genotypes for BoLA-DRB3 locus (BoLA-DRB3.2*16 and BoLA-DRB3.2*23) in Polish dairy cattle.

\section{Materials and Methods}

Data on the test-day SCC, the milk production and pedigree information were collected for 525 Polish Black-and -White Holstein cows in two experimental herds (341 cows from herd $\mathrm{K}$ and 184 cows from herd $\mathrm{P}$ ) during the study period. The cows were daughters of 133 sires in two herds. A total of 10814 test-day SCC milk samples (7828 samples from herd $\mathrm{K}$ and 2986 from herd $\mathrm{P}$ ) were recorded monthly at least five times during lactation and included into the analysis. Cows were divided into six lactations $\left(1^{\text {st }}, 2^{\text {nd }}, 3^{\text {rd }}, 4^{\text {th }}, 5^{\text {th }}\right.$, and $6^{\text {th }}$ lactation or greater $)$. Test-day SCC was logtransformed to base 10 . 
Cows were genotyped for detection of BoLA-DRB3.2*23 and BoLA-DRB3.2*16 using Multi Primer Target PCR (MPT-PCR) technique (LEDWIDGE et al. 2001).

Calculation for test-day SCC by analysis of variance using SAS GLM procedure was done. The model was fitted for BoLA genotype, herd, interaction between genotype of animals and herd, animal nested in interaction between genotype of animals and herds, lactation number, months and year of examination, regression on days of lactation and regression on milk yield.

Table 1

Association between BoLA-DRB3.2 alleles and mastitis (Beziehungen zwischen BoLA-DRB3. 2 Allelen und Mastitis)

\begin{tabular}{|c|c|c|}
\hline Reference & BoLA-DRB3.2 allele & Effects \\
\hline \multirow[b]{2}{*}{ DIETZ et al.1997 } & $* 16, * 8, * 23$ & Higher SCC (-) \\
\hline & $* 8$ & Lower SCC $(+)$ \\
\hline \multirow{5}{*}{ KELM et al. 1997} & $* 16$ & Higher EBV of SCC (-) \\
\hline & $* 8$ & More CM (-) \\
\hline & $* 11, * 23$ & Less CM $(+)$ \\
\hline & $* 24$ & More IMI with major pathogens (-) \\
\hline & *3 & More IMI with minor pathogens (-) \\
\hline \multirow{4}{*}{ STARKENBURG et al. 1997} & $* 3, * 16$ & Lower SCC (+) \\
\hline & $* 7, * 22, * 24$ & Higher SCC (-) \\
\hline & $* 24$ & More CM (-) \\
\hline & $* 8$ & Less CM $(+)$ \\
\hline & $* 16$ & Lower SCC $(+)$ \\
\hline SHARIF et al. 1998 & $* 23$ & More CM due to coli form $(-)$ \\
\hline SHARIF et al. 2000 & $* 8, * 22, * 23, * 24$ & More CM due to Staphylococcus species (-) \\
\hline
\end{tabular}

The variance components for test-day SCC were estimated by the REML (Restricted maximum likelihood) method using animal model with the software of MISZTAL (1998). Statistical analysis were accounted for fixed effects of herd, month and year of examination, lactation number, linear regression on milk yield, the random effects of permanent environment and additive genetic effect of an animal. The estimated breeding value (EVB) of SCC was calculated by the BLUP (Best linear unbiased prediction) method with the software of MISZTAL (1998). The breeding value of animals was predicted using the same model as used for the estimation of variance components. Low EBV for SCC indicates greater mastitis resistance, and high EBV indicates greater susceptibility to mastitis. The model adjusted breeding value of SCC for all animals was used to test for different genotypes using Duncan's test (SAS program).

\section{Results}

The analysis of test-day SCC indicated that BoLA-DRB3.2 genotype, herd, interaction between genotype of animals and herd, animal nested in interaction between genotype of animals and herds, lactation number, months and year of examination, and milk yield influence significantly $(\mathrm{p} \leq 0.01)$ this variable. 
Table 2

BoLA-DRB3.2 genotype effect on test-day and EBV of SCC (Der Effekt von BoLA-DRB3.2 Genotyp auf Testtag und EBV von SCC)

\begin{tabular}{lllll}
\hline $\begin{array}{l}\text { BoLA-DRB3.2 } \\
\text { genotype }\end{array}$ & Observations & Test-day SCC (LSM \pm se) & Cows & EBV of SCC (LSM \pm se) \\
\hline$* 16 /-$ & 1898 & $5.75^{\mathrm{A}, \mathrm{B}} \pm 0.12$ & 93 & $-0.51 \pm 0.85$ \\
$* 23 /-$ & 1238 & $5.91^{\mathrm{A}, \mathrm{c}, \mathrm{D} \pm 0.10}$ & 63 & $1.88^{\mathrm{A}} \pm 1.03$ \\
$* 16 / 23$ & 350 & $6.10^{\mathrm{B}, \mathrm{c}} \pm 0.12$ & 15 & $3.44^{\mathrm{B}} \pm 2.12$ \\
$-/-$ & 7328 & $5.72^{\mathrm{D}} \pm 0.10$ & 354 & $-1.65^{\mathrm{A}, \mathrm{B}} \pm 0.43$ \\
\hline
\end{tabular}

$\mathrm{A}, \mathrm{B}, \mathrm{c}$ : equal capitals differ $(\mathrm{p} \leq 0.01)$ and equal lower cases $(\mathrm{p} \leq 0.05)$.

In table 2 the least square means (LSMs) and standard error (se) of test-day SCC for the effect of BoLA-DRB3.2 genotype are presented. The results showed that BoLADRB3.2*16 / - genotype was significantly associated with lower SCC, and differed significantly ( $\mathrm{p} \leq 0.01$ ) from BoLA-DRB3.2*23 / - and BoLA-DRB3.2*16 / 23 genotype. Highest SCC was associated with animals carrying BoLA-DRB3.2*16 / 23, and differed significantly $(\mathrm{p} \leq 0.05)$ from those carrying BoLA-DRB3.2*23 / genotype. The lowest SCC was observed for cows having other alleles. LSMs of testday SCC in animals carrying other alleles differed significantly $(\mathrm{p} \leq 0.01)$ with LSMs of test-day SCC in animals having BoLA-DRB3.2 $* 23 /-$ ).

The herd effect on the test-day SCC reveals that SCC was lower in herd P and differed significantly $(\mathrm{p} \leq 0.01)$ from herd $\mathrm{K}$.

Regarding the effect of lactation on the test-day SCC, it is clearly evident that SCC increases with increasing number of lactations. LSMs of SCC for the lactation 1 to 5 differed significantly $(\mathrm{p} \leq 0.01)$ between each other. No significant differences were recorded between the $5^{\text {th }}$ and $6^{\text {th }}$ lactation.

Table 3

Proportions of variance components relative to phenotypic variance for trait SCC (Verhältnis von Varianzkomponenten zur phänotypischen Varianz für das Merkmal SCC)

Source of variation

pe $\mathrm{h}^{2} \quad \mathrm{r}$

$\begin{array}{rrr}0.42 & 0.03 & 0.45\end{array}$

$\mathrm{pe}=$ permanent environment, $\mathrm{h}^{2}=$ additive genetic (heritability), $\mathrm{r}=$ sum of additive genetic and permanent environment (repeatability).

The ratio of particular variance components, relative to phenotypic variance for testday SCC estimated by the model is presented in table 3. Heritability of log SCC is low and reaches to 0.03 . The repeatability of log SCC is high, reaching 0.45 .

Breeding value for SCC was presented in table 2. The highest EBV (unfavorable) was observed for heterozygous animals, while decreased EBV (favorable) was recorded for animals typed as BoLA-DRB3.2*16/-. Cows carrying BoLA$D R B 3.2 * 23$ / - were associated with increase of EBV for SCC in milk. There was an increase of EBV for SCC in cows carrying this allele compared to cows having BoLA-DRB3.2*16 / $-(\mathrm{p} \leq 0.07)$ or other alleles ( $\mathrm{p} \leq 0.01)$. Comparing the genotypes, EBV of animals carrying other genotype differed significantly $(\mathrm{p} \leq 0.01)$ from EBV of cows having BoLA-DRB3.2*23/- and from heterozygous animals, but there was a low number of animals carrying BoLA-DRB3.2*16 / 23. 


\section{Discussion}

Associations between genetic markers and SCC or somatic cell score (SCS) have been previously examined (AARESTRUP et al. 1995, ASHWELL et al. 1996, DIETZ et al. 1997, XU et al.2006). SCS there are individual SCC converted to score using a base 2 logarithm. Each 1-unit increase (or decrease) in score is associated with doubling (or halving) of cell count (SHOOK and SCHUTZ 1994). The present findings suggest a significant ( $\mathrm{p} \leq 0.01$ ) association between allele BoLA-DRB3.2*16 /- and lower SCC. From one hand this is consistent with the results of SHARIF et al. (1998), who recorded that BoLA-DRB3.2*16 /- was significantly $(\mathrm{p} \leq 0.05)$ associated with lower SCS in Holstein. Additionally, STARKENBURG et al. (1997) observed that BoLADRB3.2*16 was associated with decreased chronic SCS in the second lactation. This may further support the present results. On the other hand it contrast the findings of DIETZ et al. (1997) who detected an association between allele BoLA-DRB3.2*16 /and the risk of acute increases in SCC. This could be due to the fact that several different factors may have contributed to the differences between above and previous studies. These factors may have included spurious associations, differences in allele frequencies, as well as different states of linkage disequilibrium between alleles within populations. MHC is multi-gene family and it is difficult to separate the effects of specific alleles from the background (inherited en bloc) haplotype/genotype.

The level of SCC increased significantly with the increase of lactation number (AMIN2001). This reveals that with the increase of the lactation number, the number of multiparous cows is increasing and consequently increases the susceptibility to the infection, which might elevate the value of SCC. This finding is in close agreement with the findings of KIIMAN and SAVELI (2000) who studied the factors affecting milk SCC and reported that milk SCC increased with increased in lactation number. As well agree with LABOHM et al. (1998) who found that number of the lactation influenced the SCC in a statistically reliable extent, but he attributed the rise in SCC above 100000 to the infected quarter.

Somatic cell count in milk has a moderate heritability (SHOOK 1989). Heritability of SCC in the present study (0.03) was within the range $(0.02-0.14)$ reported by POSO and MANTYSAARI (1996), CARNIER et al. (1997), DETILLEUX et al. (1997) and AMIN et al. (2002), but was lower than the range $(0.06-0.09)$ reported by SAMORE et al. (2001) HINRICHS et al. (2006) and IMBAYARWO-CHIKOSI et al. (2001). However the estimated repeatability was in agreement with finding obtained by SAMORE et al. (2001). Low heritability recorded in this study could be due to small number of animals used for estimation.

Identification of individuals that are resistant to disease is desirable but difficult in commercial populations. EBV is based on phenotypic information of an individual and its family members and can be used to identify resistant individual in lieu of direct challenge. SWALVE and HÖVER (2003) recommended EBV for selection purposes. EBV is the best way to calculate relation between SCC and genotype. KELM et al. (1997) was the first who described such relation. He reported that BoLA-DRB3.2*16 /was significantly $(\mathrm{p} \leq 0.05)$ associated with higher EBV for SCC in milk, while BoLADRB3.2*23 / - was insignificantly associated with lower EBV for SCS in milk of Holstein cattle. Whereas, the findings of the present study indicated that allele BoLADRB3.2*16 / - was insignificantly $(\mathrm{p} \leq 0.07)$ associated with lower EBV for SCC in 
milk, and allele BoLA-DRB3.2*23 / - and heterozygous animals were significantly (p $\leq 0.01$ ) associated with increase of EBV for SCC in milk (Tab. 2). The difference for heterozygous animals can be influence by low number of animals carrying BoLADRB3.2*16 / 23 (Tab. 2).

The present study is the second study dealing with genetic association between BoLADRB3.2 alleles and EBV for SCC and it contrasted the results of KELM et al. (1997). It can be more reliable than that done by KELM et al. (1997) because of bigger number of analyzed animals. The differences between these two studies could be also due to differences in animal population used for such estimation. KELM et al. (1997) was using periparturient Canadian Holstein cows whereas in the present study Polish Holstein cows in different lactations (from $1^{\text {st }}$ to $6^{\text {th }}$ lactation or greater) were used. Additionally, differences are in the definition of the dependant variable (SCC versus SCS). The model used in statistical analysis and difference in allelic frequency, all can be reasons for discrepancies. Also alleles may be related to resistance or susceptibility depending on environmental conditions, which may be different in different populations. More likely, the studied polymorphisms were not causal but linked to other MHC loci involved in mastitis resistance, which would lead to different associations according to families. Thus, analysis of effect of MHC haplotypes rather then single locus should be preferred.

EBV is used instead of the phenotypic SCC information because the EBV is corrected for systemic fixed effects such as herd, age and season as well as random effects.

In conclusion BoLA-DRB3.2*16/- was associated highly significantly $(\mathrm{p} \leq 0.01)$ with lower test-day SCC and insignificantly ( $\leq 0.07$ ) with decreased EBV for SCC. Whereas, BoLA-DRB3.2*23 / - was associated highly significantly $(\mathrm{p} \leq 0.01)$ with increase of EBV for SCC in milk. EBV can be used directly to estimate the genotype effect. It can be concluded that allele BoLA-DRB3.2*16/- may indicate greater mastitis resistance, whereas BoLA-DRB3.2*23 / - may indicate greater mastitis susceptibility.

\section{Acknowledgements}

This work was supported by the Polish Ministry of Sciences Project No. 2 PO6D03026.

\section{References}

AARESTRUP, F.M.; JENSEN, N.E.; ØSTERGARD, H.:

Analysis of associations between major histocompatibility complex (BoLA) class I haplotypes and subclinical mastitis of dairy cows. J. Dairy Sci.78 (1995), 1684-1692

AMIN, A.A.:

Lactation and sample test day multi-trait animal model for genetic evaluation of somatic cell scores in Hungarian Holstein Friesian crossbreeds. Arch. Tierz. 44 (2001) 263-275

AMIN, A.A.; GERE, T.; KISHK, W.H.:

Genetic and environmental relationship among udder conformation traits and mastitis incidence in Holstein Friesian into two different environments. Arch. Tierz. 45 (2002) 129-138

ASHWELL, M.S.; REXROAD, C.E.; MILLER, R.H.; VAN RADEN, PM.:

Mapping economic trait loci for somatic cell score in Holstein cattle using microsatellite markers and selective genotyping. Anim. Genet. 27 (1996), 235-242 
BOICHARD, D.; RUPP, R.:

Genetic analysis and genetic evaluation for somatic cell score in French diary cattle. Interbull Bulletin 15 (1997), 54-60

CARNIER, P.; BETTELA, R.; CASSANDRO, M.; GALLO, L.; MANTOVANI, R.; BITTANTE, G.: Genetic parameters for test day somatic cell count in Italian Holstein Friesian cows. 48th Annual Meeting European Association of Animal Production Vienna-Austria (1997), Session IV: Mastitis control programmes 1-5

DETILLEUX, J.C.; LEROY, P.; VOLCKAERT, D.:

Alternative use of somatic cell counts in genetic selection for mastitis resistance. Interbull Bulletin 15 (1997), 34-44

DIETZ, A.B.; COHEN, N.D.; TIMMS, L.; KEHRLI, M.E.:

Bovine lymphocyte antigen class II alleles as risk factors for high somatic cell counts in milk of lactating dairy cows. J. Dairy Sci. 80 (1997), 406-412

HINRICHS, D.; STAMER, E.; JUNGE, W.; KALM, E.:

Genetic analysis of several economically important disease traits in German Holstein Cows. Arch. Tierz., 49 (2006) 3, 209-221

IMBAYARWO-CHIKOSI, E.V.; MAKUZA, S.M.; WOLLNY, C.B.A.; BANDA, J.W.:

Genetic and phenotypic parameters for individual cow somatic cell counts in Zimbabwean Holstein Fresian cattle. Arch. Tierz., 44 (2001) 2, 129-137

KELM, S.C.; DETILLEUX, J.C.; FREEMAN, A.E.; KEHRLI, M.E.; DIETZ, A.B.; FOX, L.K.; BUTLER, J.E.;

KASCKOVICS, I.; KELLEY, D.H.:

Genetic association between parameters of innate immunity and measures of mastitis in periparturient Holstein cattle. J. Dairy Sci. 80 (1997), 1767-1775

KIIMAN, H.; SAVELI, O.:

On the factors affecting milk somatic cell count in dairy cattle in Estonia. European Association for Animal Production $51^{\text {st }}$ Meeting, Netherlands (2000)

KLEIN J.; O’HUIGIN, C.:

Class II B MHC motifs in an evolutionary perspective. In: Origin of major histocompatibility complex diversity. Immunol. Rev. 143 (1995), 89-112

KÜHN, CH.; REINHARDT, F.; SCHWERIN, M.:

Marker assisted selection of heifers improved milk somatic cell count compared to selection on conventional pedigree breeding values. Arch. Tierz. 51 (2008), 23-32

LABOHM, R.; GÖTZ, E.; LUHOFER, G.; HESS, R.G.; BOSTEDT, H.:

Factors influencing the somatic milk-cell count in dairy cows.1- influence of bacteriological findings, stage and number of lactation. Milchwissenschaft 53 (1998), 63-69

LEDWIDGE, S.A.; MALLARD, B.A.; GIBSON, J.P.; JANSEN, G.B.; JIANG, Z.H.:

Multi-primer target PCR for rapid identification of bovine DRB3 alleles. Anim. Genet. 32 (2001), 219221

MIKKO, S.; ANDERSSON, L.:

Extensive MHC class II DRB3 diversity in African and European cattle. Immunogenetics 42 (1995), 408-413

MIKKO, S.; SPENCER, M.; MORRIS, B.; STABILE, S.; BASU, T.; STORMONT, C.; ANDRSSON, L.: A comparative analysis of MHC DRB3 polymorphism in the American Bison (Bison bison) J. Hered. 88 (1997), 499-503

MISZTAL, I.:

REMLF90/BLUPF90 - A flexible Mixed Model Program in Fortran 90. Manual. Animal and Dairy Science, University of Georgia, Athens, GA, USA (1998).

O’HUIGIN, C.:

Quantifying the degree of convergence in primate MHC-DRB genes. In: Origin of major histocompatibility complex diversity. Immunol. Rev. 143 (1995), 123-140

POSO, J.; MANTYSAARI, E.A.:

Relationships between clinical mastitis, somatic cell score, and production for the first three lactations of Finnish Ayrshire. J. Dairy Sci. 79 (1996), 1284-1291.

REENTS, R.; JAMROZIK, J.; SCHAEFFER, L.R.; DEKKERS, J.C.:

Estimation of genetic parameters of test day records for somatic cell score. J. Dairy Sci. 78 (1995), 2847-2857

ROGERS G.W., BANOS G., SANDER NIELSEN U., PHILIPSSON J.:

Genetic correlations among somatic cell scores, productive life, and type traits from the United States and udder health measures from Denmark and Sweden. Interbull Bulletin 14 (1996), 34-38 
SAMORE, A.B.; VAN ARENDONK, J.A.; GROE, A.F.:

Impact of area and sire by herd interaction on heritability estimates for somatic cell count in Italian Holstein Friesian cows. J. Dairy Sci. 84 (2001), 2555-2559

SCHUTZ, M.M.:

Genetic evaluation of somatic cell scores for United States dairy cattle. J. Dairy Sci.77 (1994), 21132129

SHARIF, S.; MALLARD, B.A.; SARGEANT, J.M.:

Presence of glutamine at position 74 of pocket 4 in the BoLA-DR antigen binding groove is associated with occurrence of clinical mastitis caused by Staphylococcus species. Vet. Immunol. Immunopathol. 76 (2000), 231-238

SHARIF, S.; MALLARD, B.A.; WILKIE, B.N.; SARGEANT, J.M.; SCOTT, H.M.; DEKKERS, J.C.M.;

LESLIE, K.E.:

Association of the bovine major histocompatibility complex DRB3 (BoLA-DRB3) alleles with occurrence of disease and milk somatic cell sore in Canadian dairy cattle. Anim. Genet. 29 (1998), 185-193

SHOOK, G.E.:

Selection for disease resistance. J. Dairy Sci. 72 (1989), 1349-1362

SHOOK, G.E.; SCHUTZ, M.M.:

Selection on somatic cell score to improve resistance to mastitis in the United States. J. Dairy Sci. 77 (1994), 648-658

SIGURDARDOTTIR, S.; LUNDEN, A.; ANDERSSON, L.:

Restriction fragment length polymorphism of DQ and DR class II genes of the bovine major histocompatibility complex. Anim. Genet. 19 (1988), 133-150

SPOONER, R.L.; LEVEZIEL, H.; GROSCLAUDE, F.; OLIVER, R.A.; VAIMAN, M.:

Evidence for a possible major histocompatibility complex (BoLA) in cattle. Immunogenetics 5 (1978), 335-346.

SPOONER, R.L.; OLIVER, R.A.; SALES, D.I.; MCCOUBREY, C.M.; MILLAR, P.; MORGAN, A.G.;

AMORENA, B.; BAILEY, E.; BERNOCO, D.; BRANDON, M.; BULL, R.W.; CALDWELL, J.; CWIK, S.;

VAN DAM, R.H.; DODD, J.; GAHNE, B.; GROSCLAUDE, F.; HALL, J.G.; HINES, H.; LEVEZIEL, H.;

NEWMAN, M.J.; STEAR, M.J.; STONE, W.H.; VAIMAN, M.:

Analysis of alloantisera against bovine lymphocytes. Joint report of the 1st International Bovine Lymphocyte Antigen (BoLA) workshop. Anim. Blood Groups Biochem. Genet. 10 (1979), 63-86

STARKENBURG, R.J.; HANSEN, L.B.; KEHRLI, M.E.; CHESTER-JONES, H.:

Frequencies and effects of alternative DRB3.2 alleles of bovine lymphocyte antigen for Holsteins in milk selection and control lines. J. Dairy Sci. 80 (1997), 3411-3419

SWALVE, H.H.; HÖVER, K.:

Untersuchungen an den Ergebnissen der Zuchtwertschätzung von Holstein Bullen und Kühen in Deutschland. Arch. Tierz., Dummerstorf 46 (2003) 2, 113-126

TAKESHIMA, S.; NAKAI, Y.; OHTA, M.; AIDA, Y.:

Characterization of DRB3 alleles in the MHC of Japanese Shorthorn Cattle by polymerase chain reaction-sequence-based typing. J. Dairy Sci. 85 (2002), 1630-1632.

XU, N.; PAUL, S.; BENNEWITZ, J.; REINSCH, N.; THALLER, G.; REINHARDT, F.; KÜHN, C.;

SCHWERIN, M.; ERHARDT, G.; WEIMANN, C., THOMSEN, M.; MISHRA, S.; KALM, E.:

Confirmation of quantitative trait loci for somatic cell score on bovine chromosome 18 in the German Holstein. Arch. Tierz. 49 (2006) 111-119

Received: 2007-02-08

Accepted: 2008-12-15

\author{
Authors addresses: \\ Docent Dr GRAZYNA SENDER* \\ Institute of Genetics and Animal Breeding, Polish Academy of Sciences \\ Jastrzebiec, \\ 05-552- Wolka Kosowska \\ Poland \\ email: g.sender@ighz.pl
}


Dr AGNIESZKA KORWIN-KOSSAKOWSKA,

Dr MAGDALENA SOBCZYNSKA

Institute of Genetics and Animal Breeding, Polish Academy of Sciences

Jastrzebiec,

05-552- Wolka Kosowska

Poland

Dr KARIMA GALAL ABDEL HAMEID

South Valley University,

Qena, Egypt

* Corresponding Author 